\title{
Regionalne Inwestycje Terytorialne w subregionie siedleckim 2014-2020
}

\section{Urszula Gadomska, Monika Kierzkowska}

\section{STRESZCZENIE}

Artykuł prezentuje instrument wsparcia pod nazwą Regionalne Inwestycje Terytorialne (RIT), funkcjonujący w województwie mazowieckim w perspektywie finansowej 2014-2020 oraz jego realizację w subregionie siedleckim. RIT to mechanizm finansowy utworzony przez samorząd Województwa Mazowieckiego w ramach Regionalnego Programu Operacyjnego Województwa Mazowieckiego 2014-2020, służący wsparciu powiązanych ze sobą projektów w obszarach pozametropolitalnych. Formuła RIT - oparta na podejściu terytorialnym, podobnie jak w Zintegrowanych Inwestycjach Terytorialnych dla Warszawskiego Obszaru Funkcjonalnego - pozwala na wsparcie problemowych obszarów strategicznej interwencji, zidentyfikowanych w Strategii rozwoju województwa mazowieckiego do 2030 roku. Innowacyjne Mazowsze. RIT skierowany jest do pięciu subregionów województwa mazowieckiego: ciechanowskiego, ostrołęckiego, płockiego, radomskiego i siedleckiego.

Liderem działań w obszarze strategicznej interwencji na terenie subregionu siedleckiego jest Miasto Siedlce, odpowiedzialne za skoordynowanie planu inwestycyjnego, wynikającego ze zdiagnozowanych potrzeb tego obszaru. W wyniku współpracy samorządów powiatowych subregionu zostały przygotowane dwie wiązki zintegrowanych projektów, dotyczących uzupełnienia infrastruktury transportoweji jej powiązania z transeuropejską siecią transportową orazrozwojuinfrastrukturyspołecznej, wtymszczególnieobiektówsłużbyzdrowia.Ichłącznawartośćzostałaoszacowana na ponad $400 \mathrm{mln}$ zł.

Trwającą od 2017 r. realizację planu inwestycyjnego dla subregionu siedleckiego należy uznać za duży sukces zarówno władz województwa mazowieckiego, które tworząc mechanizm RIT, umożliwiły wsparcie zintegrowanych inwestycji w obszarach pozametropolitalnych regionu oraz zmobilizowały do współpracy ich samorządy lokalne - jak i samorządów, które wypracowały plan spójnych ze sobą działań o ponadlokalnym znaczeniu dla obszaru objętego wsparciem. Zaawansowanie wykonania całego planu inwestycyjnego dla subregionu siedleckiego na koniec $2018 \mathrm{r}$. szacuje się na około $50 \%$.

Słowa kluczowe: inwestycje, dofinansowanie, subregion siedlecki, RIT

\section{Wstęp}

W przyjętej w 2013 r. Strategii rozwoju województwa mazowieckiego do 2030 roku. Innowacyjne Mazowsze wyznaczono dwa typy obszarów strategicznej interwencji (OSI): problemowe oraz bieguny wzrostu. Biegunem wzrostu w regionie jest Obszar Metropolitalny Warszawy, natomiast do OSI problemowych należą obszary: ostrołęcko-siedlecki, płocko-ciechanowski i radomski. Charakteryzują się one najniższym poziomem dostępu mieszkańców do dóbr i usług, w związku z czym wymagają interwencji z poziomu regionalnego lub krajowego. 
W celu wsparcia OSI, samorząd Województwa Mazowieckiego w ramach Regionalnego Programu Operacyjnego Województwa Mazowieckiego 2014-2020 (RPO WM 2014-2020) stworzył mechanizmy finansowe (ryc. 1):

- Zintegrowane Inwestycje Terytorialne dla Warszawskiego Obszaru Funkcjonalnego (ZIT),

- Regionalne Inwestycje Terytorialne (RIT), przeznaczone dla pięciu subregionów, rozumianych jako podregiony statystyczne (NUTS 3), funkcjonujących w dniu przyjęcia ww. programu: ciechanowskiego, ostrołęckiego, płockiego, radomskiego i siedleckiego.

Pula środków finansowych przeznaczonych na ten cel z Europejskiego Funduszu Rozwoju Regionalnego, współfinansującego RPO WM 2014-2020 w zakresie inwestycji infrastrukturalnych, wynosi $167 \mathrm{mln}$ euro na ZIT oraz ponad $200 \mathrm{mln}$ euro na RIT.

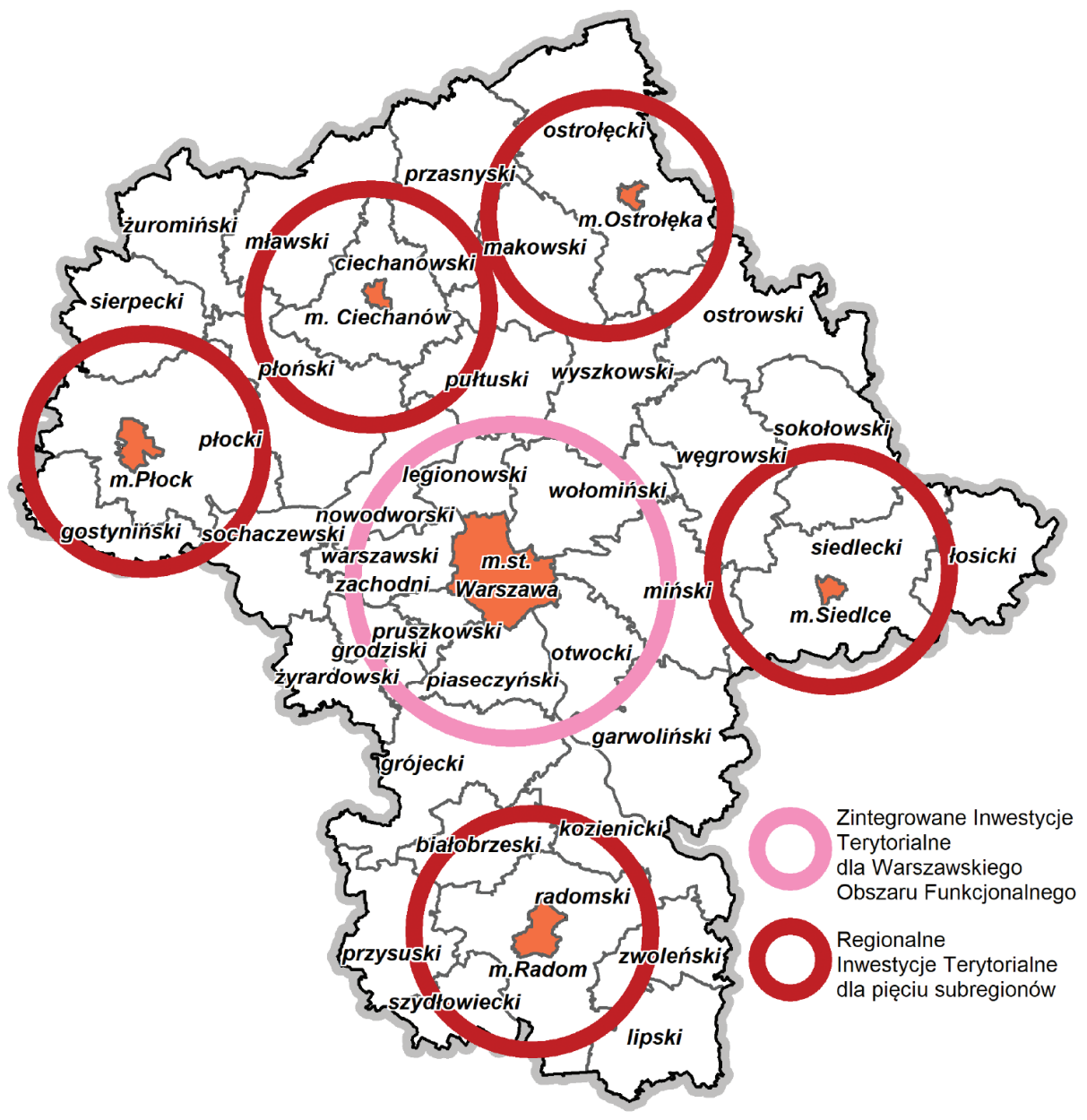

Ryc. 1. Mechanizmy RPO WM 2014-2020 adresowane do obszarów wsparcia w woj. mazowieckim Źródło: opracowanie MBPR na podstawie RPO WM 2014-2020 


\section{Zasady wsparcia w ramach RIT}

Formuła RIT - oparta, podobnie jak ZIT, na podejściu terytorialnym - zakłada preferencje w dofinansowaniu projektów, tworzących tzw. spójne wiązki, których realizacja pozwoli na kompleksowe wsparcie rozwoju subregionów województwa mazowieckiego, objętych problemowymi obszarami strategicznej interwencji. Dokumentem, na podstawie którego prowadzone jest preferencyjne finansowanie działań, jest plan inwestycyjny zawierający:

- Diagnozę problemów rozwojowych i potencjałów obszaru;

- Opis jednej lub dwóch wiązek projektów infrastrukturalnych, finansowanych z Europejskiego Funduszu Rozwoju Regionalnego;

- Opis towarzyszących projektów „miękkich”, finansowanych z Europejskiego Funduszu Społecznego;

- Plan finansowy i harmonogram czasowy.

Liderami działań w problemowych obszarach strategicznej interwencji są miasta: Radom, Płock, Siedlce, Ostrołęka i Ciechanów, będące koordynatorami planów inwestycyjnych dla poszczególnych subregionów, w których realizowane są zintegrowane inwestycje. Podstawą realizacji projektów w formule RIT jest współpraca jednostek samorządu terytorialnego, określona dowolną formą partnerstwa. Opracowanie planów inwestycyjnych wymagało dużego zaangażowania liderów i partnerów, którzy korzystali m.in. ze wsparcia merytorycznego Departamentu Rozwoju Regionalnego i Funduszy Europejskich Urzędu Marszałkowskiego Województwa Mazowieckiego, Mazowieckiego Biura Planowania Regionalnego, a także innych podmiotów działających w strukturach samorządu regionalnego.

Plany inwestycyjne, które spełniły założone kryteria oceny strategicznej, zostały przyjęte uchwałami Zarządu Województwa Mazowieckiego, co było warunkiem preferencyjnego wsparcia z RPO WM 2014-2020 projektów, określonych w tych planach (poprzez organizowanie dla nich odrębnych konkursów na dofinansowanie lub preferencję punktową w otwartych konkursach). Najwięcej projektów dotyczyło rozwoju infrastruktury drogowej oraz obiektów i usług służby zdrowia, a także działań z zakresu gospodarki niskoemisyjnej. Ze względu na to, że zamierzenia inwestycyjne w ramach RIT znacznie przekroczyły wielkość dostępnej puli finansowej, część projektów nie została dofinansowana lub uzyskała wsparcie na niższym poziomie niż pierwotnie zakładane. Powyższe szczególnie dotyczyło inwestycji w zakresie infrastruktury transportowej oraz służby zdrowia.

\section{Plan inwestycyjny dla subregionu siedleckiego}

Prace nad planem inwestycyjnym dla subregionu siedleckiego przebiegały kilkuetapowo:

- W latach 2013-2016 opracowano pierwszą wiązkę projektów infrastrukturalnych, uzupełnioną sześcioma „miękkimi” projektami towarzyszącymi - plan w takiej postaci został przyjęty uchwałą Zarządu Województwa Mazowieckiego w lipcu 2016 r.; 
- W 2017 r. plan rozszerzono o drugą wiązkę projektów infrastrukturalnych i siódmy projekt towarzyszący - uzupełnienia zostały przyjęte uchwałą Zarządu Województwa Mazowieckiego w październiku 2017 r.;

- Ponadto w latach 2016-2018 następowały niewielkie korekty planu, każdorazowo przyjmowane uchwałami Zarządu Województwa Mazowieckiego.

Pierwsze rozmowy i wstępne ustalenia dotyczące realizacji RIT wsubregionie siedleckim rozpoczęły się w 2013 r. W maju 2015 r. została zawarta oficjalna umowa partnerska pomiędzy: miastem Siedlce (miasto na prawach powiatu), powiatem siedleckim, powiatem łosickim, powiatem sokołowskim oraz powiatem węgrowskim (tworzącymi w tamtym czasie podregion statystyczny siedlecki) w sprawie współpracy przy opracowaniu i wdrażaniu planu inwestycyjnego w ramach Regionalnych Inwestycji Terytorialnych.

W szczegółowej diagnozie, sporządzonej dla przedmiotowego obszaru strategicznej interwencji, za najważniejsze problemy uznano:

a. niski poziom rozwoju gospodarczego, mierzonego wielkością PKB na mieszkańca,

b. wysoki wskaźnik migracji mieszkańców, szczególnie młodych i wykształconych,

c. wysoką stopę bezrobocia, szczególnie na obszarach wiejskich oraz wśród młodzieży do 24 roku życia,

d. niski poziom aktywności gospodarczej i mobilności mieszkańców,

e. niewystarczająco rozwinięte powiązania komunikacyjne subregionu, w tym z drogami i liniami kolejowymi Transeuropejskiej Sieci Transportowej (TEN-T),

f. niską jakość większości systemów drogowych,

g. niezadowalającą dostępność do usług publicznych, szczególnie specjalistycznych placówek ochrony zdrowia.

Zaplanowana pierwsza wiązka projektów infrastrukturalnych (ryc. 2) obejmuje utworzenie zintegrowanego wielofunkcyjnego węzła wymiany pasażerskiej w Siedlcach oraz rozbudowę i modernizację powiązanego z nim układu komunikacyjnego miasta i subregionu siedleckiego. Realizacja przyjętych projektów ma na celu uzupełnienie infrastruktury transportowej i jej powiązanie z siecią TEN-T oraz usprawnienie komunikacji, w tym szczególnie publicznej. Szacowana wartość pierwszej wiązki projektów wynosi ok. $200 \mathrm{mln} \mathrm{zł}$.

Projekt główny pierwszej wiązki dotyczy rozbudowy infrastruktury komunikacyjnej w sąsiedztwie stacji kolejowej w Siedlcach, która jest największą stacją na wschodnim odcinku magistralnej linii nr 2 (E20), będącej elementem sieci bazowej TEN-T. Zgodnie z Planem zrównoważonego rozwoju publicznego transportu zbiorowego dla województwa mazowieckiego dworzec kolejowy w Siedlcach został uznany za przyszły kluczowy węzeł przesiadkowy. Projekt główny obejmuje dwa zadania inwestycyjne w jednym ciągu drogowym:

a. budowę trzeciego etapu obwodnicy śródmiejskiej,

b. budowę tunelu pod torami kolejowymi, łączącego północną i południową część miasta z dworcem PKP i planowanym centrum przesiadkowym. 
Pozostałe projekty pierwszej wiązki dotyczą:

a. budowy centrum przesiadkowego w Siedlcach, pełniącego rolę dworca komunikacji autobusowej miejskiej i dalekobieżnej oraz parkingu P\&R,

b. budowy autobusowego centrum przesiadkowego w Sokołowie Podlaskim,

c. przebudowy i modernizacji dróg powiatowych na terenie powiatów: siedleckiego, łosickiego, sokołowskiego i węgrowskiego.

Zgodnie z opisem projektów wszystkie planowane do rozbudowy lub modernizacji drogi łączą się bezpośrednio z terenami inwestycyjnymi oraz siecią TEN-T (linia kolejowa nr 2, projektowana autostrada A2 oraz projektowana droga ekspresowa S19).

W uzasadnieniu celowości inwestycji podkreślono, że realizacja ww. wiązki projektów pozwoli na rozwiązanie wielu problemów komunikacyjnych, zidentyfikowanych szczegółowo w diagnozie zawartej w planie inwestycyjnym. System transportowy subregionu siedleckiego stanowi jeden z głównych czynników wpływających na jego rozwój. Najważniejszym węzłem komunikacyjnym tego obszaru są Siedlce, zarówno w transporcie wewnętrznym subregionu, jak i zewnętrznym - głównie w zakresie powiązań z Warszawą. Budowa dróg i centrów przesiadkowych stwarza szanse na poprawę mobilności mieszkańców oraz stworzenie korzystnych uwarunkowań dla inwestorów. Poza tym ułatwiony zostanie dostęp do transportu publicznego, szczególnie kolejowego, przez co nastąpi zmniejszenie zanieczyszczenia środowiska.

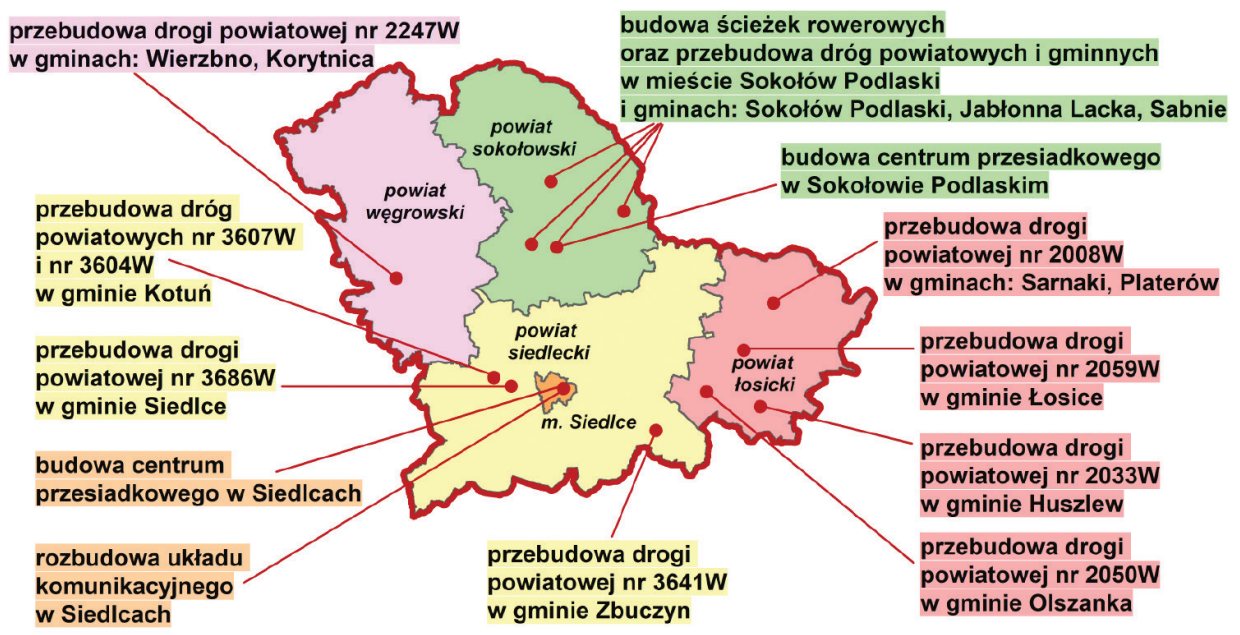

Ryc. 2. Zakres inwestycji w I wiązce projektów dla subregionu siedleckiego Źródło: opracowanie MBPR na podstawie Planu inwestycyjnego dla subregionu siedleckiego objętego OSI problemowym 
W styczniu 2017 r. został podpisany aneks do umowy partnerskiej, na mocy którego do dotychczasowych pięciu partnerów dołączył powiat garwoliński, który na podstawie Rozporządzenia Komisji (UE) 2016/2066 został przyłączony do podregionu statystycznego siedleckiego (od 1 stycznia 2018 r.). Plan inwestycyjny został uzupełniony o drugą wiązkę projektów z zakresu infrastruktury społecznej (ryc. 3). Celem realizacji przyjętych projektów jest poprawa dostępu do usług publicznych, w szczególności w zakresie specjalistycznej służby zdrowia, rewitalizacja obszarów zdegradowanych oraz podniesienie efektywności energetycznej w obiektach publicznych. Szacowana wartość drugiej wiązki projektów wynosi ok. $210 \mathrm{mln}$ zł.

Projektem głównym drugiej wiązki jest budowa Siedleckiego Ośrodka Onkologii przy Mazowieckim Szpitalu Wojewódzkim w Siedlcach, który jest największym szpitalem w subregionie, świadczącym wysokokwalifikowane usługi medyczne. W jego strukturach funkcjonuje 20 specjalistycznych oddziałów oraz 38 poradni specjalistycznych, placówka wyposażona jest również w lądowisko dla śmigłowców. Projekt główny obejmuje:

a. zakup i montaż wyposażenia technologicznego Siedleckiego Ośrodka Onkologii,

b. przeszkolenie personelu obsługującego ww. wyposażenie.

W ramach drugiej wiązki projektów zaplanowano także:

a. modernizację i doposażenie kilku oddziałów Mazowieckiego Szpitala Wojewódzkiego w Siedlcach,

b. modernizację i doposażenie wszystkich szpitali powiatowych subregionu,

c. termomodernizację obiektów publicznych w Siedlcach oraz powiatach: siedleckim, łosickim i węgrowskim.

W uzasadnieniu celowości inwestycji podkreślono, że realizacja wiązki projektów z zakresu ochrony zdrowia, ukierunkowanych przede wszystkim na budowę nowoczesnej infrastruktury szpitalnej, w znaczący sposób poprawi dostępność do wysokospecjalistycznych usług zdrowotnych. Ma to szczególne znaczenie w leczeniu chorób nowotworowych i kardiologicznych, które są główną przyczyną zgonów w województwie mazowieckim. Brak pełnego zakresu świadczeń w zakresie onkologii w subregionie siedleckim powoduje konieczność leczenia jego mieszkańców w Warszawie lub sąsiednich miastach wojewódzkich.

Realizacja projektów infrastrukturalnych, ujętych w opisanych wyżej wiązkach, pozwoli m.in. na zmniejszenie problemów społecznych, zdiagnozowanych w planie inwestycyjnym dla subregionu siedleckiego. Korzystne efekty zostaną pogłębione poprzez realizację projektów towarzyszących, dofinansowanych z Europejskiego Funduszu Społecznego, o szacowanej łącznej wartości ok. $16 \mathrm{mln}$ zł.

- Miasto Siedlce zaplanowało realizację dwóch projektów: Jestem za! Chcę się właczyć! oraz Zawodu mistrzowie - rynku pracy królowie. Celem pierwszego jest aktywizacja społeczna i zawodowa osób zagrożonych wykluczeniem społecznym i ubóstwem w celu wzmocnienia samodzielności życiowej i społecznej. Drugi projekt zakłada zwiększenie

\footnotetext{
${ }^{1}$ Rozporządzenie Komisji (UE) 2016/2066 z dnia 21 listopada 2016 r. zmieniające załączniki do rozporządzenia (WE) nr 1059/2003 Parlamentu Europejskiego i Rady w sprawie ustalenia wspólnej klasyfikacji Jednostek Terytorialnych do Celów Statystycznych (NUTS).
} 
szans na zatrudnienie uczniów szkół zawodowych subregionu siedleckiego poprzez doposażenie pracowni zawodowych, dodatkowe zajęcia dla uczniów, oferowanie usług doradcy zawodowego, realizację praktyk i staży u przedsiębiorców, a także opiekę psychologa.

- Projekt powiatu siedleckiego - Wsparcie rodzinnej pieczy zastępczej w powiecie siedleckim dotyczy tworzenia rodzinnych form opieki zastępczej poprzez pozyskiwanie i kształcenie kandydatów na rodziny zastępcze oraz organizację wyjazdów, warsztatów i zajęć dla funkcjonujących rodzin zastępczych.

- Projekt powiatu sokołowskiego - Wykształcenie zawodowe szansa na lepszy start ma na celu doskonalenie zawodowe uczniów Zespołu Szkół Nr 1 w Sokołowie Podlaskim poprzez m.in. doposażenie szkoły w nowoczesny sprzęt i materiały dydaktyczne oraz organizację dodatkowych zajęć i staży zawodowych.

- Powiat węgrowski zaplanował realizację trzech projektów: Kreuj swoja przyszłość, Okno na świat - wyrównanie dysproporcji edukacyjnych wśród uczniów szkót z terenu powiatu węgrowskiego oraz Łacznik pokoleń - cykl zajęć edukacyjno-kulturalnych dla dzieci, młodzieży oraz osób starszych z terenu powiatu węgrowskiego. Pierwszy z nich ma na celu wzrost efektywności i skuteczności kształcenia zawodowego poprzez dodatkowe zajęcia dla młodzieży, organizację praktyk i staży zawodowych, a także doposażenie szkół w sprzęt i materiały dydaktyczne. Drugi projekt skierowany jest do uczniów z różnego typu dysfunkcjami i niepełnosprawnością poprzez organizację zajęć terapeutycznych i rehabilitacyjnych oraz wsparcie psychologicznopedagogiczne, a trzeci ma na celu wielopokoleniową integrację mieszkańców na terenach zagrożonych marginalizacją.

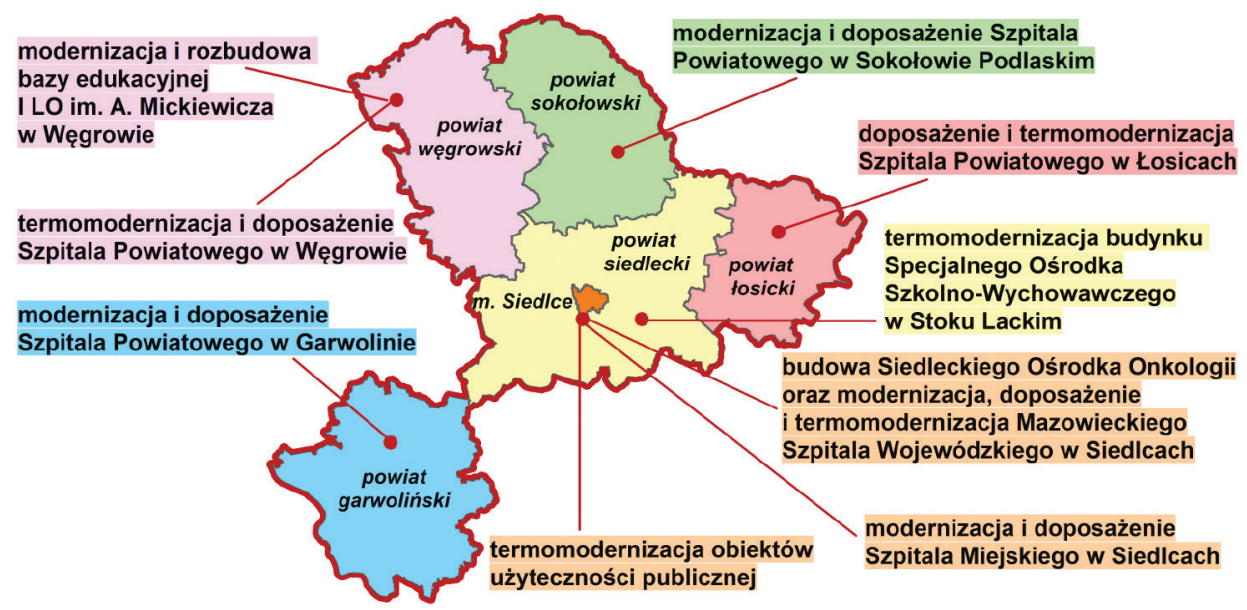

Ryc. 3. Zakres inwestycji w II wiązce projektów dla subregionu siedleckiego

Źródło: opracowanie MBPR na podstawie Planu inwestycyjnego dla subregionu siedleckiego objętego OSI problemowym 


\section{Realizacja planu inwestycyjnego dla subregionu siedleckiego - stan na koniec 2018 r.}

Zaawansowanie wykonania całego planu inwestycyjnego dla subregionu siedleckiego na koniec 2018 r. szacuje się na około 50\%. W latach 2017-2018 została zrealizowana większość projektów z zakresu infrastruktury komunikacyjnej (I wiązka), w tym zakończony w czerwcu 2018 r. projekt główny - budowa tunelu pod torami oraz rozbudowa infrastruktury komunikacyjnej w ciągu ulicy Rotmistrza W. Pileckiego w Siedlcach (o wartości 56,4 mln zł i dofinansowaniu z RPO WM 2014-2020 w wysokości 33,4 mln zł). Łączna wartość projektów pierwszej wiązki, zrealizowanych do końca 2018 r., wyniosła $122,9 \mathrm{mln}$ zł, a ich dofinansowanie 77,9 mln zł. W trakcie realizacji pozostał tylko projekt pod nazwą Utworzenie centrum przesiadkowego w Sokołowie Podlaskim wraz z rozbudowa powiazanego z nim układu komunikacyjnego powiatu sokołowskiego(o wartości 55,2 mln i dofinansowaniu 42,8 mln zł), planowany do zakończenia w $2020 \mathrm{r}$.

Realizacja projektów z zakresu infrastruktury społecznej (II wiązka) rozpoczęła się dopiero w 2018 r. Wówczas podpisano umowy na wsparcie z RPO WM 2014-2020 projektu głównego - budowy Siedleckiego Ośrodka Onkologii (o wartości $55 \mathrm{mln}$ zł i dofinansowaniu w wysokości $41,5 \mathrm{mln}$ zł) oraz szeregu innych inwestycji w szpitalu wojewódzkim oraz szpitalu miejskim w Siedlcach - o łącznej wartości 85,8 mln zł i dofinansowaniu 65,1 mln zł. Część projektów, biorących udział w konkursach, m.in. dotyczących modernizacji i doposażenia szpitali w Siedlcach i Łosicach, mimo pozytywnej oceny nie otrzymała dofinansowania z powodu niewystarczającej puli środków. Zakończenie projektów drugiej wiązki przewidziane jest na koniec $2020 \mathrm{r}$.

Spośród projektów towarzyszących, rozpoczęto jedynie realizację projektu miasta Siedlce Zawodu mistrzowie - rynku pracy królowie (o wartości 2,2 mln zł i dofinansowaniu w kwocie 1,7 mln zł).

\section{Podsumowanie i wnioski}

Trwającą realizację planu inwestycyjnego dla subregionu siedleckiego (zaawansowanie na koniec 2018 r. wynosi około 50\%) w formule mechanizmu finansowego pod nazwą Regionalne Inwestycje Terytorialne, stworzonego w ramach RPO WM 2014-2020, należy uznać za duży sukces. Jest to sukces zarówno władz województwa mazowieckiego, które tworząc ww. mechanizm umożliwiły wsparcie zintegrowanych inwestycji w obszarach pozametropolitalnych regionu oraz zmobilizowały do współpracy ich samorządy lokalne, jak i samorządów, które wypracowały plan spójnych ze sobą działań o ponadlokalnym znaczeniu dla obszaru objętego wsparciem.

Oprócz wymiernych efektów w postaci zrealizowanych projektów, ogromną wartością mechanizmu RIT w subregionie siedleckim są długookresowe efekty społeczne - spodziewane zarówno wśród mieszkańców, korzystających z rozbudowanych i zmodernizowanych systemów transportowych oraz obiektów infrastruktury społecznej, jak i w środowisku władz samorządowych, które wypracowały zasady 
partnerskiej współpracy oraz zidentyfikowały wspólne problemy i potrzeby, wymagające zintegrowanych działań także w przyszłości.

Doświadczenia, zdobyte podczas realizacji planów inwestycyjnych dotyczących obszarów strategicznej interwencji w perspektywie finansowej 2014-2020, powinny zostać wykorzystane $\mathrm{w}$ dalszych działaniach na rzecz rozwoju regionu. W celu wzmocnienia potencjału subregionu siedleckiego - obszaru odgrywającego istotną rolę $\mathrm{w}$ procesach rozwojowych zachodzących w województwie mazowieckim - niezbędna jest $\mathrm{m}$.in. realizacja wielokierunkowych przedsięwzięć, podejmowanych także przez podmioty inne niż samorządowe, m.in. organy administracji rządowej, organizacje pozarządowe, podmioty gospodarcze. Duże znaczenie w tych procesach mają działania informacyjne i promocyjne, kierowane do właściwych jednostek decyzyjnych oraz opinii publicznej, które będą służyły podnoszeniu świadomości społecznej oraz aktywizacji i partycypacji społeczeństwa.

\section{Słownik skrótów}

NUTS 3 - poziom trzeci (podregion) w Nomenklaturze Jednostek Terytorialnych do Celów Statystycznych

OSI - Obszary Strategicznej Interwencji

RIT - Regionalne Inwestycje Terytorialne

RPO WM 2014-2020 - Regionalny Program Operacyjny Województwa Mazowieckiego 2014-2020

TEN-T - Transeuropejska Sieć Transportowa

ZIT - Zintegrowane Inwestycje Terytorialne dla Warszawskiego Obszaru Funkcjonalnego

\section{Dokumenty i akty prawne}

Plan inwestycyjny dla subregionu siedleckiego objętego OSI problemowym - przyjęty Uchwałą nr 1102/166/16 Zarządu Województwa Mazowieckiego z dnia 12 lipca 2016 r. z późniejszymi zmianami.

Plan zrównoważonego rozwoju publicznego transportu zbiorowego dla województwa mazowieckiego przyjęty Uchwałą nr 217/14 Sejmiku Województwa Mazowieckiego z dnia 3 listopada 2014 r.

Regionalny Program Operacyjny Województwa Mazowieckiego 2014-2020 - zatwierdzony przez Komisję Europejską w dniu 12 lutego 2015 r.

RIT RPO Mazowieckie - załącznik do RPO WM 2014-2020.

Rozporządzenie Komisji (UE) 2016/2066 z dnia 21 listopada 2016 r. zmieniajace załaczniki do rozporządzenia (WE) nr 1059/2003 Parlamentu Europejskiego i Rady w sprawie ustalenia wspólnej klasyfikacji Jednostek Terytorialnych do Celów Statystycznych (NUTS).

Strategia rozwoju województwa mazowieckiego do 2030 roku - przyjęta Uchwałą nr 158/13 Sejmiku Województwa Mazowieckiego z dnia 28 października 2013 r. 
136 | REGIONALNE INWESTYCJE TERYTORIALNE W SUBREGIONIE SIEDLECKIM 2014-2020

Urszula Gadomska, Monika Kierzkowska

\section{Strony internetowe}

www.funduszedlamazowsza.eu

www.podlasie24.pl

www.siedlce.pl

www.tygodniksiedlecki.com

\section{Inne źródła}

Dane Mazowieckiej Jednostki Wdrażania Programów Unijnych 


\section{Regional Territorial Investments in the Siedlce subregion 2014-2020}

\section{ABSTRACT}

The article presents a support instrument under the name Regional Territorial Investments (RIT), operating in the Mazowieckie Voivodeship in the financial perspective 2014-2020 and its implementation in the Siedlce subregion. RIT is a financial mechanism created by the self-government of Mazowieckie Voivodeship as part of the Regional Operational Program of the Mazowieckie Voivodeship 2014-2020, supporting the related projects in non-metropolitan areas. The RIT formula - based on a territorial approach, similarly to the Integrated Territorial Investments for the Warsaw Functional Area - allows to support the problem areas of strategic intervention identified in the Mazowieckie Voivodship Development Strategy until 2030. Mazovia as an Innovative Region. The RIT is directed to 5 subregions of the Mazowieckie Voivodeship: Ciechanów, Ostrołęka, Płock, Radom and Siedlce.

The leader of the activities in the area of strategic intervention in the Siedlce subregion is the City of Siedlce, responsible for coordinating the investment plan resulting from the diagnosed needs of this area. As a result of cooperation of county subregions, two groups of integrated projects were prepared, concerning the complement of transport infrastructure and its connection with the trans-European transport network and the development of social infrastructure, including in particular health care facilities. Their total value has been estimated over PLN 400 million.

The implementation of the investment plan for the Siedlce subregion since 2017 should be regarded as a great success - both by the Mazowieckie Voivodeship authorities, which created the RIT mechanism, enabled the support of the integrated investments in non-metropolitan areas of the region and mobilized their local governments and local governments that worked out the plan of coherent activities about over local significance for the area covered by the support. The completion of the entire investment plan for the Siedlce subregion at the end of 2018 is estimated at around 50\%.

Keywords: investments, funding, Siedlce subregion, RIT

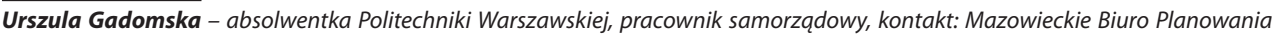
Regionalnego w Warszawie, Oddział Terenowy w Siedlcach, ul. Pułaskiego 19/21, 08-110 Siedlce, e-mail: ugadomska@mbpr.pl

Urszula Gadomska, a graduate of the Warsaw University of Technology, public administration employee, contact: Mazovian Office for Regional Planning in Warsaw, Branch office in Siedlce, ul. Pułaskiego 19/21 08-110 Siedlce, e-mail: ugadomska@mbpr.pl

Monika Kierzkowska - absolwentka Akademii Podlaskiej (obecnie Uniwersytet Przyrodniczo-Humanistyczny) w Siedlcach, Studia Podyplomowe w zakresie Funduszy Strukturalnych Unii Europejskiejna Uniwersytecie Kardynała Stefana Wyszyńskiego w Warszawie, pracownik samorządowy, kontakt: Mazowieckie Biuro Planowania Regionalnego w Warszawie, Oddział Terenowy w Siedlcach, ul. Pułaskiego 19/21, 08-110 Siedlce, e-mail: mkierzkowska@mbpr.pl

Monika Kierzkowska, a graduate of the Faculty of Management in Siedlce (now University of Natural Sciences and Humanities), postgraduate of the Faculty of Structural Funds of the European Union from the Cardinal Wyszynski University in Warsaw, public administration employee, contact: Mazovian Office for Regional Planning in Warsaw, Branch office in Siedlce, ul. Pułaskiego 19/21, 08-110 Siedlce, e-mail: mkierzkowska@mbpr.pl 